\title{
Knowledge and practice regarding menstrual hygiene among physically disabled women in Kathmandu, Nepal Bishal Pokhrel1, Sunita Mahat ${ }^{2}$, Kriti Parajuli ${ }^{3}$
}

Department of Community Medicine

Karnali Academy of Health Sciences, Jumla, Nepal

\begin{abstract}
${ }^{1}$ Assistant Professor, Department of Community Medicine and Public Health, Karnali Academy of Health Sciences, Jumla, Nepal. 2Department of Public Health, National Academy for Medical Sciences, Purbanchal University, Kathmandu, Nepal.

${ }^{3}$ MA Food and Nutrition, Padma Kanya Multiple Campus, Kathmandu, Nepal
\end{abstract}

\begin{abstract}
Background and Objectives: Disability is the condition of difficulty in carrying out daily activities normally and in taking part in social life due to problems in parts of the body and the physical system. Disability also carries stigma, so disabled people may face layers of discrimination when they are menstruating. The objective of the review is to assess the menstrual hygiene practice of disabled women, the barriers they face, and the available interventions to help them manage their menstruation hygienically and with dignity.
\end{abstract}

Material and Methods: This was a cross-sectional descriptive study that was conducted among 151 physically disabled peoples.Self-structured questionnaire and face-to-face interview was used as data collection tools and techniques. Data entry and analysis was done using SPSS 16.0. The results of the study were presented with the help of tabular description using the same software along with Microsoft word and excel 2007.

Results: Most of respondents knew the 26-30 days as normal cycle duration (80.13\%). Majority of respondents had reported that they do not go to holy places (91.39\%) and should not cook food $(94.03 \%)$ during menstruation. Most of respondents had stayed $(96.68 \%)$ and eat $(98.01 \%)$ at same place and $31.38 \%$ of respondents had bath daily during menstruation. $83.44 \%$ of respondents used sanitary while $69.53 \%$ of respondents changed pad twice a day. Maximum number of the respondents $91.39 \%$ disposed sanitary pad in dustbin. $87.41 \%$ of respondents learned about menstrual hygiene from parents.

Conclusion: Good and satisfactory knowledge about menstrual hygiene was found among girls of age group 15-24years.

Key Words: Knowledge, practice, menstrual hygiene and physically disabled

\section{INTRODUCTION}

Disability is the condition of difficulty in carrying out daily activities normally and in taking part in social life due to problems in parts of the body and the physical system as well as obstacles created by physical, social, cultural environment and by communication [1]. Prevailing illiteracy, ignorance, and negative perception on the disability in the society it is considered as the punishment of the god for some sin committed in the past 
life but it is not so. It is a human reality that occurs in all the ages from birth to old age [2].

The onset of menstruation is one of the most important changes occurring among the girls during the adolescent. Menstruation and menstrual practices are still clouded by taboos and socio-cultural restrictions resulting in adolescent girls remaining ignorant of the scientific facts and hygienic health practices, which sometimes result into adverse health outcomes [3].

According to population census 2068, nearly $2 \%$ of total population of Nepal are disabled and among them $44 \%$ of them are female. In $44 \%$ of female disables, $36 \%$ are physically disabled [4]. Most obstetrician-gynecologists will encounter adolescents with disabilities in their practice. Reproductive health issues such as puberty, sexuality, and menstruation can be more complicated for teenagers with disabilities and their families as a result of concerns surrounding menstrual hygiene, abuse risk, vulnerability, and altered mood [5]. Hygiene-related practices of women during menstruation are of considerable importance, as it has a health impact in terms of increased vulnerability to RTI [6]. In this condition menstruation and disability both are affected by socio-cultural factors. Thus our study will help to find out how disable women are vulnerable to menstrual hygiene problems and their practice.

\section{MATERIAL AND METHODS}

A structured questionnaire was developed. The questionnaire had been designed to collect socio-demographic information, food frequency, and dietary diversification, diet pattern. Self-administered questionnaire in Nepali language had been provided to the respondents and were explained about the questions. The research was approved by ethical research committee of CAFODAT College. Total 250 Medical Representatives were randomly selected for research, out of which 231 accepted to participate in the study and gave appointment. The descriptive, cross sectional study was conducted to assess the knowledge and practice regarding mensuration hygiene among physically disables women in Disable Rehabilitation Center, Jorpati area of Kathmandu. Sample size was calculated by the $(\mathrm{n})=\frac{z^{\mathrm{z}} \mathrm{p}(1-\mathrm{p})}{d^{2}}$. Where, $\mathrm{n}=$ sample size, $\mathrm{P}=$ expected prevalence or proportion, $\mathrm{d}=$ precision, $\mathrm{Z}=\mathrm{Z}$ statistic for a level of confidence. We have, $\mathrm{p}=$ $0.89 \%=0.52(7), d=5 \%=0.05, Z=1.96$ for $95 \%$ confidence interval, $1-\mathrm{p}=0.49$. Then, $\mathrm{n}=$ $1.96 \times 1.96 \times 0.89(0.11) / 0.05 \times 0.05=151$. Data was collected from15 Feb to 15 March 2018. The required sample size was 151. Semistructured questionnaire was used to collect data. Written consent was obtained from each respondent. Confidentiality was assured and maintained. Data was entered in statistical package for social science (SPSS) version 20 and analyzed and interpreted in terms of descriptive (Frequency, Percentage)

\section{RESULTS}

Socio-demographic status of the respondents is presented in table 1. It was found that more than about half of the respondents (56.29\%) were of age group 15-24 years. Majority of the respondents i.e. $94.03 \%$ were found to be unmarried. Nearly four number of respondents (74.17\%) followed Hindu religion. Majority of the respondents were Brahmin (31.12\%) and followed Janajati (23.17\%). Regarding educational status, $13.24 \%$ of the respondents had achieved secondary, 37.08\% primary, 5.29\% Higher Secondary while $27.81 \%$ were literate and 
$16.55 \%$ were illiterate. More than one third numbers of respondents (38.41\%) had disability related to lower limb, 30.46\% had upper and lower, and $22.51 \%$ had with Upper limb. The $91.39 \%$ of respondents reported the right age of menarche. Maximum number

\begin{tabular}{|c|c|c|}
\hline $\begin{array}{c}\text { Socio- } \\
\text { demographic } \\
\text { characteristics }\end{array}$ & $\begin{array}{c}\text { Frequency } \\
(n=151)\end{array}$ & $\begin{array}{c}\text { Percent } \\
(\%)\end{array}$ \\
\hline \multicolumn{3}{|l|}{ Age (In Years) } \\
\hline $15-24$ & 85 & 56.29 \\
\hline $25-34$ & 43 & 28.47 \\
\hline$>34$ & 23 & 15.23 \\
\hline \multicolumn{3}{|l|}{ Marital status } \\
\hline Unmarried & 142 & 94.03 \\
\hline Married & 9 & 5.97 \\
\hline Divorced & 0 & 0 \\
\hline Separated & 0 & 0 \\
\hline \multicolumn{3}{|l|}{ Religion } \\
\hline Hindu & 112 & 74.17 \\
\hline Buddhist & 25 & 16.55 \\
\hline Christian & 14 & 9.27 \\
\hline \multicolumn{3}{|l|}{ Ethnicity } \\
\hline Bhramin & 47 & 31.12 \\
\hline Janajati & 35 & 23.17 \\
\hline Chettri & 43 & 28.47 \\
\hline Dalit & 22 & 14.56 \\
\hline Other & 4 & 2.64 \\
\hline \multicolumn{3}{|l|}{ Educational status } \\
\hline Illiterate & 25 & 16.55 \\
\hline Literate & 42 & 27.81 \\
\hline Primary & 56 & 37.08 \\
\hline Secondary & 20 & 13.24 \\
\hline Higher Secondary & 8 & 5.29 \\
\hline \multicolumn{3}{|l|}{ Type of disability } \\
\hline Lower limb & 58 & 38.41 \\
\hline Head neck spinal & 13 & 8.60 \\
\hline Upper n lower & 46 & 30.46 \\
\hline Upper limb & 34 & 22.51 \\
\hline
\end{tabular}

(80\%) of respondents reported the 26-30 days as normal cycle duration. Majority of respondents (91.39\%) reported that they do not go to holy places during menstruation and should not cook food during menstruation. Only $3.31 \%$ of respondents had taken health education class or training related to menstrual hygiene. It was found that $87.41 \%$ of respondents were informed about mensuration by their parents whereas other was taught by teachers and course books.

Maximum number of respondents (96.68\%) reported that they stayed at same place

Table 2: Knowledge regarding menstrual hygiene, $\mathrm{n}=\mathbf{1 5 1}$

\begin{tabular}{|l|l|l|}
\hline $\begin{array}{l}\text { Knowledge regarding } \\
\text { menstrual hygiene }\end{array}$ & $\begin{array}{l}\text { Frequency } \\
(\mathrm{n}=151)\end{array}$ & $\begin{array}{l}\text { Percent } \\
(\%)\end{array}$ \\
\hline
\end{tabular}

Normal age to begin menstruation

\begin{tabular}{|l|l|l|}
\hline $11-15$ & 138 & 91.39 \\
\hline Others & 13 & 8.60 \\
\hline
\end{tabular}

Normal flow of bleeding

\begin{tabular}{|l|l|l|}
\hline 3-5 days & 102 & 67.54 \\
\hline $5-7$ days & 49 & 32.45 \\
\hline Normal cycle duration & \multicolumn{2}{|l|}{} \\
\hline $26-30$ days & 121 & 80.13 \\
\hline $30-35$ & 26 & 17.21 \\
\hline Others & 7 & 4.63 \\
\hline
\end{tabular}

Go to holy places during period

\begin{tabular}{|c|c|c|}
\hline No & 138 & 91.39 \\
\hline Yes & 13 & 8.61 \\
\hline \multicolumn{3}{|c|}{ Cook food during period } \\
\hline No & 142 & 94.03 \\
\hline Yes & 9 & 5.96 \\
\hline \multicolumn{3}{|c|}{ Taken training/health education class } \\
\hline No & 146 & 96.68 \\
\hline Yes & 5 & 3.31 \\
\hline
\end{tabular}

Source of knowledge about menstruation

\begin{tabular}{|l|l|l|}
\hline Parents & 132 & 87.41 \\
\hline Teachers & 13 & 8.60 \\
\hline Course book & 6 & 3.97 \\
\hline
\end{tabular}




\begin{tabular}{|c|c|c|}
\hline $\begin{array}{l}\text { Practice regarding } \\
\text { menstrual hygiene }\end{array}$ & $\begin{array}{l}\text { Frequency } \\
(n=151)\end{array}$ & $\begin{array}{l}\text { Percent } \\
(\%)\end{array}$ \\
\hline \multicolumn{3}{|l|}{ Stay during period } \\
\hline Same place & 146 & 96.68 \\
\hline Separate place & 5 & 3.31 \\
\hline \multicolumn{3}{|l|}{ Time of bath } \\
\hline 1st day & 26 & 17.21 \\
\hline 4th day & 65 & 43.04 \\
\hline Daily & 48 & 31.78 \\
\hline Others & 12 & 7.94 \\
\hline \multicolumn{3}{|l|}{\begin{tabular}{|l|} 
Place to eat food \\
\end{tabular}} \\
\hline Same place & 148 & 98.01 \\
\hline Outside kitchen & 3 & 1.98 \\
\hline \multicolumn{3}{|l|}{ Type of pad } \\
\hline Clothes & 25 & 16.55 \\
\hline Sanitary pad & 126 & 83.44 \\
\hline \multicolumn{3}{|l|}{ Period to change pad } \\
\hline Change daily & 16 & 10.59 \\
\hline Twice a day & 105 & 69.53 \\
\hline Depends upon situation & 30 & 19.86 \\
\hline \multicolumn{3}{|l|}{ Share common pads } \\
\hline No & 150 & 99.33 \\
\hline Yes & 1 & 0.66 \\
\hline \multicolumn{3}{|l|}{ Reuse pad } \\
\hline No & 146 & 96.68 \\
\hline Yes & 5 & 3.31 \\
\hline \multicolumn{3}{|l|}{ Place of pad disposal } \\
\hline Mud & 5 & 3.31 \\
\hline Dustbin & 138 & 91.39 \\
\hline Separate place & 8 & 5.29 \\
\hline \multicolumn{3}{|c|}{ Information about menstrual hygiene } \\
\hline Parents & 61 & 40.39 \\
\hline Friends & 16 & 10.59 \\
\hline Book & 46 & 30.46 \\
\hline None & 6 & 3.97 \\
\hline Others & 22 & 14.56 \\
\hline \multicolumn{3}{|c|}{ Technique to clean genitalia } \\
\hline Anterior to posterior & 53 & 35.09 \\
\hline Posterior to anterior & 5 & 3.31 \\
\hline Haphazardly & 93 & 61.58 \\
\hline \multicolumn{3}{|l|}{ Way of cleaning } \\
\hline Soap and water & 133 & 88.07 \\
\hline Plane water & 18 & 11.92 \\
\hline \multicolumn{3}{|l|}{ Rest } \\
\hline No & 15 & 9.93 \\
\hline Yes & 136 & 90.06 \\
\hline
\end{tabular}

respondents reported that they bath daily during menstrual period. Maximum number of respondents (98.01\%) reported that they eat food at same place. It was found that, 83 $.44 \%$ of respondents used sanitary pad and $50 \%$ of respondents changed pad twice a day.

Table 4: Health related information of the
respondents. n=151
\begin{tabular}{|l|l|l|}
\hline $\begin{array}{l}\text { Health related } \\
\text { information }\end{array}$ & $\begin{array}{l}\text { Frequency } \\
\text { (n=151) }\end{array}$ & $\begin{array}{l}\text { Percent } \\
\text { (\%) }\end{array}$ \\
\hline Face common problem during period \\
\hline No & 26 & 17.21 \\
\hline Yes & 125 & 82.78 \\
\hline Common problems & 68 & 45.03 \\
\hline Dysmenorrhea & 34 & 22.51 \\
\hline Exclusive blood flow & 49 & 32.45 \\
\hline Premenstrual symptom & & \\
\hline Coping strategy & 23 & 15.23 \\
\hline Medicine & 34 & 22.51 \\
\hline Diet food & 26 & 17.21 \\
\hline Hot water bag & 68 & 45.03 \\
\hline Rest
\end{tabular}

Among the respondents $99.33 \%$ did not share common pads and $96.68 \%$ did not re use pad. Regarding disposal of Pads, $91.39 \%$ of respondents disposed pad in dustbin, $5.29 \%$ in separate place and $3.31 \%$ in mud. It was also found that, $40.39 \%$ of respondents learned about menstrual hygiene from parents, $10.59 \%$ from friends, $30.46 \%$ from books ,3.97 \% none and $14.56 \%$ from others. Among the respondents, $61.58 \%$ clean genitilia haphazardly while $35.09 \%$ anterior to posterior and 3.31\% Posterior to anterior. Most of the respondents $88.07 \%$ use soap and water to clean genitalia.

Maximum number of respondents reported that they take rest during mensuration and $82.78 \%$ face common problems during menstruation. The common Problems they 
face during menstruation were, $45.03 \%$ dysmenorrhea, 22.51\% abnormal blood flow and $32.45 \%$ premenstrual symptom. To cope with common problems reported above, $45.03 \%$ took rest, $17.21 \%$ used hot water bag, $22.51 \%$ had diet food, and $15.23 \%$ of respondents took medicine.

\section{DISCUSSION}

The findings of the study show that $56.29 \%$ were of age group 15-24 while $28.47 \%$ of 25 34 and $15.23 \%$ were above 34 years. Majority of the respondents i.e. $94.03 \%$ were found to be unmarried. Majority of the respondents were Brahmin (31.12\%) and Janajati (23.17\%). Regarding educational status, $13.24 \%$ of the respondents had achieved secondary, 37.08\% primary, 5.29\% Higher Secondary while $27.81 \%$ were literate and16.55 \% were illiterate. Maximum number of respondents (38.41\%) had disability related to lower limb. The study conducted in North India also shows similar age group of menstrual cycle [6].

In the present study disable women of Kathmandu, Nepal, the most common informant to inform about menstruation was mother. Dysmenorrhea was the commonest problem faced during menstruation (45.03\%) followed by back pain and excessive blood loss. Maximum number of respondents (83.44\%) used sanitary pads and frequency of changing pads twice a day was highest. Same study conducted in India and Nepal also shows same results [7-10].

In this study, maximum number of respondents (94.03\%) reported that they take rest during mensuration and they are restricted to go to holy places, cooking and touching to male as similar to the study conducted in Uttarkhand, India [3].

The use of sanitary pads and change twice a day by disabled females is only some percent high than normal female which was expected to be higher but it is different from other study [7, 12]. Only $3.31 \%$ of respondents had taken health education class or training related to menstrual hygiene, which show the same results [6]. This shows that there is still a strong existence of misconception regarding menstruation in the society.

Out of 160 respondents of Uttarkhand, India, for cleaning purpose, (97.5\%) girls used both soap and water [6]. Among the respondents, $61.58 \%$ clean genitilia haphazardly while $35.09 \%$ anterior to posterior and 3.31\% Posterior to anterior. Most of the respondents $88.07 \%$ use soap and water to clean genitilia. Also, $31.78 \%$ of respondents reported they that they bath daily during menstrual period. The use of soap and water while cleaning is less.

The limitations of this study are as this is done in Urban area of Disable Rehabilitation Center, Jorpati, Kathmandu. The findings would provide base line data for future study. Based on finding further research with different design, sampling technique and size involving in rural to generalize in Nepal.

\section{CONCLUSION}

More than one third of the respondents had disability related to lower limb. Disability by birth and accident were found to be equal while disability due to disease was found to be low. One third of the respondents reported that they bath during menstrual period. $4 / 5^{\text {th }}$ of the respondents used sanitary pad while 
nearly three fourth of respondents changed pad twice a day. Majority of the respondents disposed pad in dustbin. More than half of the respondents clean their genitalia haphazardly. Among them, majority used soap and water to clean genitalia.

Maximum number of respondents reported that they take rest during menstruation and face common problems like dysmenorrheal. It was also found that, below half of respondents learned about menstrual hygiene from parents. Only minimum number of respondents had taken health education class or training related to menstrual hygiene.

\section{ACKNOWLEDGEMENT}

We researchers would like to express heartfelt thanks to rehabilitation centers (Disability Newlife Center, National Disability Women Association, National Disabled Association, Disable Rehabilitation center, Khagendra Disable School) Jorpati, Kathmandu. Researcher's sense of gratitude and appreciation go to all the respondents and participated in this study.

\section{REFERENCES}

1. Definition and classification of disability in Nepal. Government of Nepal; 2006.

2. Sharma J. A Study on the Social Status of Women with Disabilities.2007.

3. Dasgupta S. Menstrual Hygiene: How Hygienic is the Adolescent Girl? Indian J Community Med. 2008;33(2):77-80.

4. People with Disability: Central Bureau of Statistics; 2011.

5. Arbor A. Menstrual and reproductive issues in adolescents with physical and developmental disabilities. 2014 Aug;124(2):367-75.

6. Misra P UR, Sharma V, Anand K, Gupta V. A community-based study of menstrual hygiene practices and willingness to pay for sanitary napkins among women of a rural community in northern India. The National Medical Journal of India. 2013 Nov-Dec;26(6):335-7.

7. Thakur H, AA. et al. Knowledge, Practices, and Restrictions Related to Menstruation among Young Women from Low Socioeconomic Community in Mumbai, India. Jul 3, 2014.

8. Sapkota D, SD, Budhathoki SS3, Khanal VK, Pokharel HP. Knowledge and practices regarding menstruation among school going adolescents of rural Nepal. 2013;2(5):117-21.

9. Rupa Vani K, Bupathy A. Menstrual Abnormalities in School Going Girls - Are They Related to Dietary and Exercise Pattern?. Journal of Clinical and Diagnostic Research. 2013; November:7(11).

10. Kamath R GD, Lena A, Chandrasekaran V. A study on knowledge and practices regarding menstrual hygiene among rural and urban adolescent girls in Udupi Taluk, Manipal, India. Global Journal of Medicine and Public Health. 2013;2(4).

\section{Corresponding Author: Dr. Bishal Pokhrel Assistant Professor Department of Commnity Medicine and Public Health, Karnali Academy of Health Sciences, Jumla, Nepal Email: dr.bishalpokhrel@gmail.com}

